\title{
\begin{tabular}{l|l} 
Mibraries & DSpace@MIT
\end{tabular}
}

\author{
MIT Open Access Articles
}

\section{Combined Technologies for Microfabricating Elastomeric Cardiac Tissue Engineering Scaffolds}

The MIT Faculty has made this article openly available. Please share how this access benefits you. Your story matters.

Citation: Guillemette, Maxime D. et al., "Combined Technologies for Microfabricating Elastomeric Cardiac Tissue Engineering Scaffolds." Macromolecular Bioscience 10, 11 (November 2010): 1330-37 (C2010 Authors

As Published: https://dx.doi.org/10.1002/mabi.201000165

Publisher: Wiley-Blackwell

Persistent URL: https://hdl.handle.net/1721.1/129997

Version: Author's final manuscript: final author's manuscript post peer review, without publisher's formatting or copy editing

Terms of use: Creative Commons Attribution-Noncommercial-Share Alike 


\title{
Combined Technologies for Microfabricating Elastomeric Cardiac Tissue Engineering Scaffolds
}

\author{
Maxime D. Guillemette ${ }^{1}$, Hyoungshin Park ${ }^{1}$, James C. Hsiao ${ }^{2}$, Saloni R. Jain ${ }^{1}$, Benjamin L. \\ Larson $^{1}$, Robert Langer ${ }^{1}$, and Lisa E. Freed ${ }^{1,2, *}$ \\ ${ }^{1}$ Harvard-MIT Division of Health Sciences \& Technology, Massachusetts Institute of Technology, \\ Cambridge, MA, USA \\ 2 Biomedical Engineering and MEMS Fabrication Group, Charles Stark Draper Laboratory, \\ Cambridge, MA, USA
}

\begin{abstract}
Polymer scaffolds that direct elongation and orientation of cultured cells can enable tissue engineered muscle to act as a mechanically functional unit. We combined micromolding and microablation technologies to create muscle tissue engineering scaffolds from the biodegradable elastomer poly(glycerol sebacate). These scaffolds exhibited well defined surface patterns and pores and robust elastomeric tensile mechanical properties. Cultured $\mathrm{C} 2 \mathrm{C} 12$ muscle cells penetrated the pores to form spatially controlled engineered tissues. Scanning electron and confocal microscopy revealed muscle cell orientation in a preferential direction, parallel to micromolded gratings and long axes of microablated anisotropic pores, with significant individual and interactive effects of gratings and pore design.
\end{abstract}

\section{Keywords}

Biodegradable; Cell Orientation; Elastomers; Microfabrication; Tissue Engineering

\section{Introduction}

Tissue engineering seeks to restore the function of diseased or damaged tissue with limited capacity for self-repair, such as the heart, typically through the use of cells and polymeric scaffolds. ${ }^{[1]}$ In many tissues, including heart, ${ }^{[2,3]}$ smooth, ${ }^{[4]}$ and skeletal muscle, ${ }^{[5]}$ a highly organized structure of oriented lamellae plays a critical role in determining mechanical function. Toward functional regeneration of damaged heart muscle, feasibility of implanting cell sheets ${ }^{[6]}$ and cells embedded in hydrogels ${ }^{[7]}$ were demonstrated in vivo, and restoration of pumping by repopulation of decellularized hearts was demonstrated in vitro. ${ }^{[8]}$ These studies have inspired new approaches to creating scaffolds resembling normal heart tissue by exploiting state-of-the art polymer and microfabrication technologies. ${ }^{[9]}$

Polymeric two-dimensional (2D) cell culture substrates providing topographical cues that guide the alignment of cultured cells have been produced by a variety of methods, ${ }^{[10]}$ including photolithography, ${ }^{[11,12]}$ embossing, ${ }^{[13]}$ and microcontact printing. ${ }^{[14-17]}$ Topographically micropatterned surfaces induced cultured cells, ${ }^{[12]}$ including muscle cells, ${ }^{[18]}$ to form an oriented layer that in turn induced self-assembly of additional, consistently organized layers of cells and extracellular matrix (ECM). However, formation

*Address for Correspondence Lisa E. Freed, MD., Ph.D. C.S. Draper Laboratory, 555 Technology Square, MS 32, Cambridge, MA 02139-4307 USA Tel: (617) 258-4234; Fax:(617)-258-3858; 1freed@ draper.com. 
of a mechanically functional tissue requires long in vitro culture durations of at least 6 weeks. ${ }^{[12]}$

Porous three-dimensional (3D) tissue engineering scaffolds providing space for cell penetration and nascent tissue development, ${ }^{[19]}$ mass transport in vitro ${ }^{[20]}$ and/or vascularization in vivo ${ }^{[21]}$ have been produced by a variety of methods including freezedrying, ${ }^{[22,23]}$ knitting, ${ }^{[24]}$ electrospinning, ${ }^{[25]}$ selective laser sintering, ${ }^{[26]}$ particulate leaching without or with superimposed flow channels, ${ }^{[20,27-29]}$ stereolithography, ${ }^{[30]}$ cellhydrogel molding, ${ }^{[31]}$ and laser microablation. ${ }^{[32]}$ However, previous $3 \mathrm{D}$ tissue engineering scaffolds did not guide cell alignment to the degree present in heart muscle. ${ }^{[32]}$ Moreover, previous scaffolds often failed to match the mechanical properties of normal heart muscle. ${ }^{[24,32,33]}$ In the present study, we sought to enhance muscle cell guidance in the context of a micropatterned, porous elastomeric scaffold by a novel combination of micromolding and microablation technologies. Since many naturally occurring and thermoplastic polymers fail under long-term cyclic loading, we selected poly (glycerol sebacate) (PGS), a robust biodegradable elastomer, ${ }^{[34]}$ as the scaffold material. We and others recently showed the mechanical properties of PGS can be tailored to match heart muscle, ${ }^{[32,33]}$ and that PGS is slowly biodegradable by surface hydrolysis. ${ }^{[35,36]}$

While recognizing the challenges of cell sourcing for cardiac tissue engineering, ${ }^{[37]}$ we tested the scaffolds with cultured C2C12 muscle cells which are well characterized, ${ }^{[38]}$ electrically excitable ${ }^{[39]}$ and can provide proof-of-concept for new cardiac tissue engineering technologies. ${ }^{[20,26]}$ Based on previous demonstrations of enhanced muscle cell alignment, we used replica molding to produce surface features with dimensions on the order of $5-10 \mu \mathrm{m},{ }^{[13]}$ and laser microablation to produce top-to-bottom pores on the order of $200 \mu \mathrm{m} .{ }^{[32]}$ Specifically, we sought to demonstrate preferential alignment of cultured muscle cells in parallel to linear gratings and long axes of anisotropic pores on microfabricated PGS scaffolds.

\section{Experimental Part}

\section{Silicon molding}

Mylar mask transparencies were generated by CAD/Art Services (Bandon, OR) using an Orbotech 7008 laser photo-plotter (Billerica, MA) at 20,000 dpi. Starting substrates were $100 \mathrm{~mm}$ diameter, $525 \mu \mathrm{m}$ thick silicon wafers (Montco Silicon Technology, Spring City, PA). A photoresist adhesion promoter, hexamethyldisilazane, was spun at $4000 \mathrm{rpm}$ for $30 \mathrm{~s}$ and hotplate baked at $95^{\circ} \mathrm{C}$ for $60 \mathrm{~s}$, followed by Shipley 1822 positive photoresist (Dow, Indianapolis, IN), spun at $4000 \mathrm{rpm}$ for $30 \mathrm{~s}$, targeting $2.4 \mu \mathrm{m}$ thickness, and oven baked at $92^{\circ} \mathrm{C}$ for $30 \mathrm{~min}$. Both materials were spun on an EVG101 spray coater/spinner (EVG, Tempe, AZ). UV exposure was applied using a MA-6 Photo Aligner (Suss Microtech, Waterbury Center, VT) in hard contact mode for $9 \mathrm{~s}$. The wafers were then developed in Microposit MF319 (Microchem, Newton, MA) for $55 \mathrm{~s}$, rinsed in deionized water for $5 \mathrm{~min}$, and spun-dry. An oxygen plasma step was performed in a PX-250 plasma asher (March Plasma Systems, Concord, CA) at $55 \mathrm{~W}$ for $5 \mathrm{~min}$. The wafers were then hard-baked at $110^{\circ} \mathrm{C}$ for $30 \mathrm{~min}$ in an oven. The exposed silicon was etched in an STS ICP (Surface Technology Systems, Newport, UK), targeting a depth of $10 \mu \mathrm{m}$. Photoresist was stripped by oxygen plasma (March, $100 \mathrm{~W}, 5 \mathrm{~min}$ ) followed with $20 \mathrm{~min}$ in SVC-14 photoresist stripper (Dow). A final cleaning was done using a piranha bath $\left(1: 1, \mathrm{H}_{2} \mathrm{SO}_{4}: \mathrm{H}_{2} \mathrm{O}_{2}\right)$ for 20 min. Targeted groove depth was verified using a Wyko NT-1100 optical interferometer (Veeco, Fremont, CA). 


\section{Preparation of scaffolds}

PGS pre-polymer was synthesized by polycondensation of 0.1 mole each of glycerol (Aldrich, Milwaukee, WI) and sebacic acid (Aldrich) as previously described. ${ }^{[34]}$ Resulting product was stored as is for later use. For production of PGS membranes $\sim 250 \mu \mathrm{m}$ thick, 1.5 $\mathrm{g}$ of pre-polymer was melted on sucrose-coated silicon wafers at $160^{\circ} \mathrm{C}$ and then cured at 40 mtorr and $160^{\circ} \mathrm{C}$ for $8 \mathrm{~h}^{[32]}$. Membranes were delaminated in distilled water $(\mathrm{dH} 2 \mathrm{O})$ at $60^{\circ} \mathrm{C}$ for $12 \mathrm{~h}$ and rinsed in $70 \%$ ethanol (VWR, West Chester, PA) for $12 \mathrm{~h}$. Membranes were then placed on sucrose-coated glass slides and top-to-bottom pores were drilled using a microablation system (LSX-213, CETAC, Omaha, NE). Specifically, a frequency quintupled $(213 \mathrm{~nm}) \mathrm{Nd}$ :YAG pulsed laser was used with a $150 \mu \mathrm{m} \times 150 \mu \mathrm{m}$ aperture, at a total energy of $4.3 \mathrm{~mJ}(100 \%)$, a frequency of $20 \mathrm{~Hz}$, and 160 shots per pore. Gratings, if present, were positioned face-down on the glass slide for their protection during laser drilling. Scaffolds were delaminated in $\mathrm{dH} 2 \mathrm{O}$ at $60^{\circ} \mathrm{C}$ for $3 \mathrm{~h}$ and rinsed in $70 \%$ ethanol for $12 \mathrm{~h}$. Two distinct groups of PGS membranes (LINE and Control (CTL), respectively) were produced by using silicon wafers with and without gratings, and two distinct pore designs (square (SQ) and rectangular (RECT), respectively) were produced by using either one square aperture or two square apertures superimposed with $20 \mu \mathrm{m}$ overlap.

\section{Preparation of tissue engineered constructs}

The murine myoblast cell line $\mathrm{C} 2 \mathrm{C} 12$ was obtained from ATCC (Manassas, VA) and the culture medium was Dulbecco's Modified Eagle Medium (DMEM, Invitrogen, Grand Island, NY) supplemented with 10\% fetal bovine serum (Invitrogen) and 1\% penicillinstreptomycin (Invitrogen) as previously described. ${ }^{[39]}$ The PGS scaffolds were cut into 5 $\mathrm{mm} \times 5 \mathrm{~mm}$ pieces, placed in custom-made Teflon wells $(5 \mathrm{~mm} \times 5 \mathrm{~mm} \times 4.7 \mathrm{~mm}$ deep $)$, autoclave-sterilized, and pre-coated with a fibronectin-collagen solution to enhance cell attachment (FNC Coating Mix ${ }^{\circledR}$; AthenaES, Baltimore, MD). Five million C2C12 muscle cells were resuspended in $100 \mu \mathrm{L}$ of culture medium and pipetted onto each PGS scaffold. After a $3 \mathrm{~h}$ period of cell seeding in a $37^{\circ} \mathrm{C}, 5 \% \mathrm{CO}_{2}$ humidified incubator, constructs were transferred into poly(ethylene terephthalate)(PET) cell culture inserts in 12-well plates (BD Falcon, Bedford, MA) and $5 \mathrm{~mL}$ of medium were added per well. The cell-seeded scaffolds were cultured for 12 days, with complete medium replacement every 2 or 3 days. For each condition, 3 samples were tested in 2 different experiments.

\section{Mechanical testing}

Mechanical testing methods were adapted from our previous study. ${ }^{[32]}$ Rectangular strips of bulk PGS membrane $(5 \times 2 \mathrm{~mm})$ and microfabricated PGS scaffolds $(5 \times 2 \mathrm{~mm})$ were prepared and their thicknesses measured using a dial gauge (L.S. Starrett, Athol, MA). Dry specimens were mounted on an Electroforce ELF 3200 mechanical tester (Bose-Enduratec, Framingham, MA) fitted with custom fabricated stainless steel tissue grips and a $250 \mathrm{~g}$ load cell (model 31-1435-03; Sensotech, Columbus, $\mathrm{OH}$ ). Specimens were uniaxially strained to failure at $0.1 \mathrm{~V}$ per second. Independent specimens were tested in two directions: a preferred direction (PD) wherein tensile stretch was applied in parallel to the grating and in some cases the long axes of rectangular pores, and an orthogonal cross-preferred direction (XD). Elastic moduli (E-PD; E-XD) were determined by linear regression within the linear region of the stress-strain curves up to a strain of $10 \%$, since this was within the average physiological strain range for muscle tissue. ${ }^{[40,41]}$ Ultimate tensile strengths (UTS-PD, UTS-XD) were determined as the maximum stresses measured prior to the onset of failure. For each condition, 3 samples were tested in 2 different experiments. 


\section{Scanning electron microscopy (SEM)}

SEM was performed on dehydrated scaffolds using a Hitachi S3500 (Hitachi High Technologies America, Pleasanton, CA) and a Zeiss Supra VP35 (Carl Zeiss SMT, Peabody, MA). Samples were subjected to a series of increasing ethanol concentrations and critical point drying. Dehydrated samples were sputter-coated with Au-Pd alloy using a 108auto Sputter Coater (Cressington Scientific Instruments, Watford, UK).

\section{Confocal microscopy}

Actin-phalloidin staining was done as described previously. ${ }^{[32]}$ In brief, full-thickness specimens were rinsed, fixed in 10\% neutral buffered formalin (Sigma, St. Louis, MO) for 2 $\mathrm{h}$, rinsed, extracted in $0.2 \%(\mathrm{v} / \mathrm{v})$ Triton X-100 (Sigma) in phosphate buffered saline (PBS) for $2 \mathrm{~h}$, rinsed, pre-incubated in 1\% (w/v) bovine serum albumin (Sigma) in PBS for $2 \mathrm{~h}$, incubated in Alexa Fluor 488-phalloidin (2:150 (v/v) dilution; Molecular Probes) for $3 \mathrm{~h}$, rinsed, and incubated in DRAQ5 (25 $\mu \mathrm{M}$ in PBS; Biostatus Limited, Leicestershire, UK) for $30 \mathrm{~min}$, all at room temperature. Specimens were bulk mounted on glass slides in Fluoromount (Southern Biotech, Birmingham, AL) and coverslipped. Specimens were imaged on a Zeiss LSM 510 laser scanning confocal microscope and F-actin, and nuclei were pseudo-colored green and blue, respectively.

\section{Cell orientation measurement}

Cell alignment was assessed using a method adapted from a previous study. ${ }^{[12]}$ In brief, SEM images were used to identify orientations for all cells located inside the pores and around the pores at the scaffold surfaces. The orientation of the cellular long axis was calculated as the angle deviation (AD) with respect to the gratings for scaffolds with micropatterning, and with respect to the long axis of rectangular pores or a randomly selected edge of the square pore for scaffolds without gratings, using Image $\mathrm{J}$ software from NIH (Bethesda, MD). For each condition, at least 3 different images of 6 pores were evaluated.

\section{Statistical analysis}

Data were calculated as mean \pm standard deviation. Tissue culture data were analyzed using a standard analysis of variance (ANOVA) in conjunction with Tukey's post hoc test using general linear model and pair-wise comparison. Mechanical test data were analyzed by standard Student-t test. Statistical significance was established as $\mathrm{p}<0.05$.

\section{Results \& Discussion}

Toward enhancing orientation of cultured muscle cells on porous tissue engineering scaffolds by contact guidance phenomena, the intervening structural elements (i.e., struts) were micropatterned with linear gratings. The first step to achieving the design concept was to produce a silicon master mold with the desired topographical features and to render this design in PGS by replica molding. Standard photolithography was used to create a doubleridged pattern $(10 \mu \mathrm{m}$ wide $\times 10 \mu \mathrm{m}$ spaced $\times 10 \mu \mathrm{m}$ deep features $)$ at $170 \mu \mathrm{m}$ intervals in the silicon master (Figure 1a), and targeted feature depth was verified by interferometer imaging (Figure 1b). Fabrication of the intended design in $\sim 250 \mu \mathrm{m}$ thick PGS membranes was readily achieved (Figures 1c and 1d). Very few defects were observed and de-molding was simplified by sucrose-coating the silicon master. ${ }^{[11]}$ The second step to achieving the design concept was to produce pores in the PGS such that the intervening struts retained the micromolded gratings. Laser microablation was used to produce top-to-bottom pores with linear dimensions ranging from $150-280 \mu \mathrm{m}$. To protect the micropattern, membranes were positioned on sucrose-coated glass slides with the gratings facing downwards and then laser drilled (Figure 2a). 
Using membranes with gratings, two different pore designs were produced with good precision: square pores of $150 \mu \mathrm{m} \times 150 \mu \mathrm{m}$ (SQ LINE, Figures $2 \mathrm{~b}$ and c) and rectangular pores of $280 \mu \mathrm{m} \times 150 \mu \mathrm{m}$ (RECT LINE, Figures $2 \mathrm{~d}$ and e). Using non-patterned membranes, the same two pore designs were produced by laser drilling to provide otherwise identical control scaffolds (SQ CTL and RECT CTL, data not shown). Whereas topographical micropatterning of cell culture substrates was demonstrated at cell- and tissuerelevant length scales more than a decade ago, ${ }^{[42]}$ and 3D scaffolds with anisotropic pores for muscle tissue engineering were more recently reported, ${ }^{[28,31,32,43]}$ the present work focused on combining microfabrication technologies in the context of a slowly biodegradable elastomer in order to create a scaffold capable of enabling organized cell alignment and providing mechanical function of the resulting engineered tissue $a$ priori.

Mechanical properties were measured for three types of specimens with gratings: PGS membranes and PGS scaffolds from the SQ LINE and RECT LINE groups (Figures 1c, 2b, and $2 \mathrm{~d}$, respectively), with application of tensile stretch in two directions: in parallel or orthogonal to the grating (preferred direction, $\mathrm{PD}$, and cross-preferred direction, $\mathrm{XD}$, respectively). Measured values of elastic modulus (E) and ultimate tensile strength (UTS) in each direction are shown in Figure 3. For the PGS membranes, grating orientation with respect to direction of tensile stretch did not affect E or UTS, presumably due to the minimal contribution of the gratings $(<10 \%)$ to the overall membrane cross-sectional area (Figure 3 ). Also for PGS scaffolds from the SQ LINE group, grating orientation with respect to stretch direction did not affect E or UTS, presumably due to in-plane isotropy of these scaffolds. However, for PGS scaffolds from the RECT LINE group, co-orientation of gratings and long rectangular pore axes in the direction of tensile stretch significantly increased E (E-PD, $889 \pm 116 \mathrm{kPa} v s$. E-XD, $521 \pm 52 \mathrm{kPa}, \mathrm{p}<0.05$ ) and tended to increase UTS (UTS-PD, $507 \pm 136 \mathrm{kPa} v s$. UTS-XD, $401 \pm 41 \mathrm{kPa}, \mathrm{p}>0.05$ ), presumably due to in-plane anisotropy of these scaffolds and consistent with our previous report. ${ }^{[32]}$ Values of E and UTS for PGS scaffolds in this study (Figure 3), obtained over a linear strain range of 0 to 0.1 , were somewhat higher than corresponding values previously reported for adult human heart muscle (E, 20-500 kPa and UTS, 3-15 kPa, where these ranges reflect progressive, nonlinear increases with strain (reviewed in ${ }^{[33]}$ ). Efforts to further optimize the design and fabrication scaffolds that more closely match the mechanical properties of native myocardium are underway. ${ }^{[26,33]}$

While recognizing the challenge of developing optimal cell sources for cardiac tissue engineering, ${ }^{[37]} \mathrm{C} 2 \mathrm{C} 12$ cells were used in this study as a model to evaluate muscle cell alignment capability of microfabricated PGS scaffolds. Cells were cultured for 12 days and imaged using SEM and confocal microscopy. SEM images from each group of scaffolds (SQ CTL, SQ LINE, RECT CTL, and RECT LINE) shown in Figure 4. Confocal micrographs of actin-phalloidin stained specimens from each group are shown at low and high magnification in Figure 5. Cell orientation, defined as an angle deviation of the cellular long axis with respect to the gratings and/or pore edge (Figure 6a), was quantified based on SEM images, since gratings were not visible by confocal microscopy due to PGS autofluorescence. Cellular alignment within a 10 degree variation from the grating axis is presented for all four scaffold groups (Figure 6b) and for each individual group (Figures $6 \mathrm{c}-$ f). There were statistically significant differences between each group, except between the SQ LINE and RECT CTL groups (Figure 6b). A progressive increase in cell orientation was observed as follows: SQ CTL < SQ LINE and RECT CTL < RECT LINE. These findings suggest that scaffolds enabled cultured muscle cells to preferentially align in parallel to linear gratings and pore edges, with significant individual and interactive effects of surface topography and anisotropic pore design. Thus, combined physical cues for cell elongation and orientation, i.e., topographical features and pores, produced more organized engineered muscle tissue. Previously, it was reported that cells cultured on 2D micropatterned substrates 
exhibited a range of responses that depend on cell type, feature size, and geometry. ${ }^{[44-46]}$ With regard to the cell types present in muscle tissue, topographical features with dimensions on the order of 2-10 $\mu \mathrm{m}$ were associated with alignment of cultured $\mathrm{C} 2 \mathrm{C} 12$ muscle cells, ${ }^{[13,18]}$ fibroblasts, ${ }^{[47]}$ endothelial cells, ${ }^{[48]}$ and neonatal rat heart cells. ${ }^{[17]}$ In the present study, $\mathrm{C} 2 \mathrm{C} 12$ muscle cells aligned in response both to linear surface features on the order of $10 \mu \mathrm{m}$ and to the long axes of micro-scale anisotropic pores. The novelty of the present work is in the combination of precisely controllable surface topographies and pore designs to achieve interactive effects on cell alignment at the surfaces and within the pores of a biodegradable elastomeric scaffold, which possess suitable mechanical properties, resulting in a functional engineered-tissue $a$ priori, as would be needed for repair of damaged muscle. Importantly, these same techniques can be applied to cell types other than $\mathrm{C} 2 \mathrm{C} 12$ muscle cells, and ongoing extension of the present studies to neonatal rat heart cells suggest that heart cell elongation, alignment, and contractility may also be improved by a combined microtechnologies approach.

\section{Conclusion}

Micropatterning and microablation technologies were combined in the context of an elastomeric scaffold for muscle tissue engineering. Patterns of gratings and pores were created that could be varied in a highly controlled manner. The resulting scaffolds exhibited anisotropic, elastomeric mechanical properties, an important characteristic of normal muscle. Cellular orientation, demonstrated and quantified using $\mathrm{C} 2 \mathrm{C} 12$ muscle cells on the different PGS scaffolds, suggested significant individual effects of each individual technology and further improvement when the two microtechnologies were used in combination.

\section{Acknowledgments}

Major funding for this work was provided by the American Recovery and Reinvestment Act (ARRA), Award Number 1-R01-HL086521-01A2 (to LEF) from the National Heart, Lung and Blood Institute (NHLBI). Additional funds were from C.S. Draper laboratory (to LEF), NIH DE013023 and NSF BES-0609182 (to RL). The content is solely the responsibility of the authors and does not necessarily represent the official views of the NHLBI or NIH. We are indebted to G.C. Engelmayr, Jr., J.T. Borenstein, T. Langdo and L. Racz for many useful discussions, J. Wang for help with polymer synthesis, E. Kim for help with mechanical design, N. Watson for help with confocal microscopy, and R.J. Gauvin for help with statistical analyses.

\section{References}

1. Langer R, Vacanti JP. Science. 1993; 260:920. [PubMed: 8493529]

2. Anderson RH, Smerup M, Sanchez-Quintana D, Loukas M, Lunkenheimer PP. Clin Anat. 2009; 22:64. [PubMed: 18567009]

3. Pope AJ, Sands GB, Smaill BH, LeGrice IJ. Am J Physiol Heart Circ Physiol. 2008; 295:H1243. [PubMed: 18641274]

4. Fay FS, Delise CM. Proc Natl Acad Sci U S A. 1973; 70:641. [PubMed: 4197624]

5. Lieber RL, Bodine-Fowler SC. Phys Ther. 1993; 73:844. [PubMed: 8248293]

6. Furuta A, Miyoshi S, Itabashi Y, Shimizu T, Kira S, Hayakawa K, Nishiyama N, Tanimoto K, Hagiwara Y, Satoh T, Fukuda K, Okano T, Ogawa S. Circ Res. 2006; 98:705. [PubMed: 16469955]

7. Zimmermann WH, Melnychenko I, Wasmeier G, Didie M, Naito H, Nixdorff U, Hess A, Budinsky L, Brune K, Michaelis B, Dhein S, Schwoerer A, Ehmke H, Eschenhagen T. Nat Med. 2006; 12:452. [PubMed: 16582915]

8. Ott HC, Matthiesen TS, Goh SK, Black LD, Kren SM, Netoff TI, Taylor DA. Nat Med. 2008; 14:213. [PubMed: 18193059]

9. Freed LE, Engelmayr GC, Borenstein JT, Moutos FT, Guilak F. Advanced Materials. 2009; 21:3410. [PubMed: 20882506] 
10. Bettinger CJ, Langer R, Borenstein JT. Angew Chem Int Ed Engl. 2009; 48:5406. [PubMed: 19492373]

11. Bettinger CJ, Orrick B, Misra A, Langer R, Borenstein JT. Biomaterials. 2006; 27:2558. [PubMed: 16386300]

12. Guillemette MD, Cui B, Roy E, Gauvin R, Giasson CJ, Esch MB, Carrier P, Deschambeault A, Dumoulin M, Toner M, Germain L, Veres T, Auger FA. Integrative Biology. 2009; 1:196. [PubMed: 20023803]

13. Charest JL, Garcia AJ, King WP. Biomaterials. 2007; 28:2202. [PubMed: 17267031]

14. Chiu DT, Jeon NL, Huang S, Kane RS, Wargo CJ, Choi IS, Ingber DE, Whitesides GM. Proc Natl Acad Sci U S A. 2000; 97:2408. [PubMed: 10681460]

15. Shi J, Wang L, Chen Y. Langmuir. 2009; 25:6015. [PubMed: 19466769]

16. Badie N, Satterwhite L, Bursac N. Ann Biomed Eng. 2009; 37:2510. [PubMed: 19806455]

17. Badie N, Bursac N. Biophys J. 2009; 96:3873. [PubMed: 19413993]

18. Zhao Y, Zeng H, Nam J, Agarwal S. Biotechnology and Bioengineering. 2009; 102:624. [PubMed: 18958861]

19. Cheng M, Moretti M, Engelmayr GC, Freed LE. Tissue Eng Part A. 2009; 15:645. [PubMed: 18759675]

20. Maidhof R, Marsano A, Lee EJ, Vunjak-Novakovic G. Biotechnol Prog. 2010

21. Sundararaghavan HG, Metter RB, Burdick JA. Macromol Biosci. 2009; 10:265. [PubMed: 20014198]

22. Leor J, Aboulafia-Etzion S, Dar A, Shapiro L, Barbash IM, Battler A, Granot Y, Cohen S. Circulation. 2000; 102:III56. [PubMed: 11082363]

23. Kroehne V, Heschel I, Schugner F, Lasrich D, Bartsch JW, Jockusch H. J Cell Mol Med. 2008; 12:1640. [PubMed: 18194451]

24. Boublik J, Park H, Radisic M, Tognana E, Chen F, Pei M, Vunjak-Novakovic G, Freed LE. Tissue Eng. 2005; 11:1122. [PubMed: 16144448]

25. Zong X, Bien H, Chung C-Y, Yin L, Fang D, Hsiao BS, Chu B, Entcheva E. Biomaterials. 2005; 26:5330. [PubMed: 15814131]

26. Yeong WY, Sudarmadji N, Yu HY, Chua CK, Leong KF, Venkatraman SS, Boey YC, Tan LP. Acta Biomater. 2009

27. Gao X, Tao W, Lu W, Zhang Q, Zhang Y, Jiang X, Fu S. Biomaterials. 2006; 27:3482. [PubMed: 16510178]

28. Radisic M, Park H, Chen F, Salazar-Lazzaro JE, Wang Y, Dennis R, Langer R, Freed LE, VunjakNovakovic G. Tissue Eng. 2006; 12:2077. [PubMed: 16968150]

29. Radisic M, Park H, Martens TP, Salazar-Lazaro JE, Geng W, Wang Y, Langer R, Freed LE, Vunjak-Novakovic G. J Biomed Mater Res A. 2008; 86:713. [PubMed: 18041719]

30. Engelmayr GC Jr. Papworth GD, Watkins SC, Mayer JE Jr. Sacks MS. J Biomech. 2006; 39:1819. [PubMed: 16043186]

31. Bian W, Bursac N. Biomaterials. 2009; 30:1401. [PubMed: 19070360]

32. Engelmayr GC Jr. Cheng M, Bettinger CJ, Borenstein JT, Langer R, Freed LE. Nat Mater. 2008; 7:1003. [PubMed: 18978786]

33. Chen QZ, Bismarck A, Hansen U, Junaid S, Tran MQ, Harding SE, Ali NN, Boccaccini AR. Biomaterials. 2008; 29:47. [PubMed: 17915309]

34. Wang Y, Ameer GA, Sheppard BJ, Langer R. Nat Biotechnol. 2002; 20:602. [PubMed: 12042865]

35. Wang Y, Kim YM, Langer R. J Biomed Mater Res A. 2003; 66:192. [PubMed: 12833446]

36. Pomerantseva I, Krebs N, Hart A, Neville CM, Huang AY, Sundback CA. J Biomed Mater Res A. 2009; 91:1038. [PubMed: 19107788]

37. Jawad H, Lyon AR, Harding SE, Ali NN, Boccaccini AR. Br Med Bull. 2008; 87:31. [PubMed: 18790825]

38. McMahon DK, Anderson PA, Nassar R, Bunting JB, Saba Z, Oakeley AE, Malouf NN. Am J Physiol Cell Physiol. 1994; 266:C1795. 
39. Park H, Bhalla R, Saigal R, Radisic M, Watson N, Langer R, Vunjak-Novakovic G. J Tissue Eng Regen Med. 2008; 2:279. [PubMed: 18512267]

40. Choi HF, D'Hooge J, Rademakers FE, Claus P. Conf Proc IEEE Eng Med Biol Soc. 2009; 2009:2887. [PubMed: 19964050]

41. Vetter FJ, McCulloch AD. Ann Biomed Eng. 2000; 28:781. [PubMed: 11016415]

42. Bhatia SN, Chen CS. Biomedical Microdevices. 1999; 2:131.

43. Jean AH, Engelmayr GC Jr. Journal of Biomechanics. [accepted].

44. Brunette DM. Exp Cell Res. 1986; 164:11. [PubMed: 3956588]

45. Flemming RG, Murphy CJ, Abrams GA, Goodman SL, Nealey PF. Biomaterials. 1999; 20:573. [PubMed: 10213360]

46. Teixeira AI, Nealey PF, Murphy CJ. J Biomed Mater Res A. 2004; 71:369. [PubMed: 15470741]

47. Chou L, Firth JD, Uitto VJ, Brunette DM. J Cell Sci. 1995; 108(Pt 4):1563. [PubMed: 7615675]

48. Lu J, Rao MP, MacDonald NC, Khang D, Webster TJ. Acta Biomater. 2008; 4:192. [PubMed: 17851147] 
a)
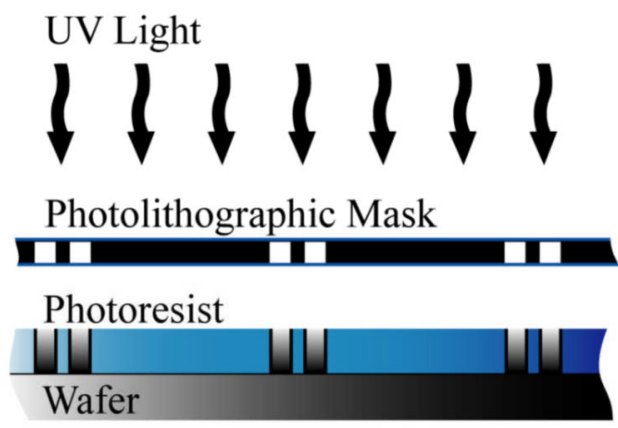

\section{b)}
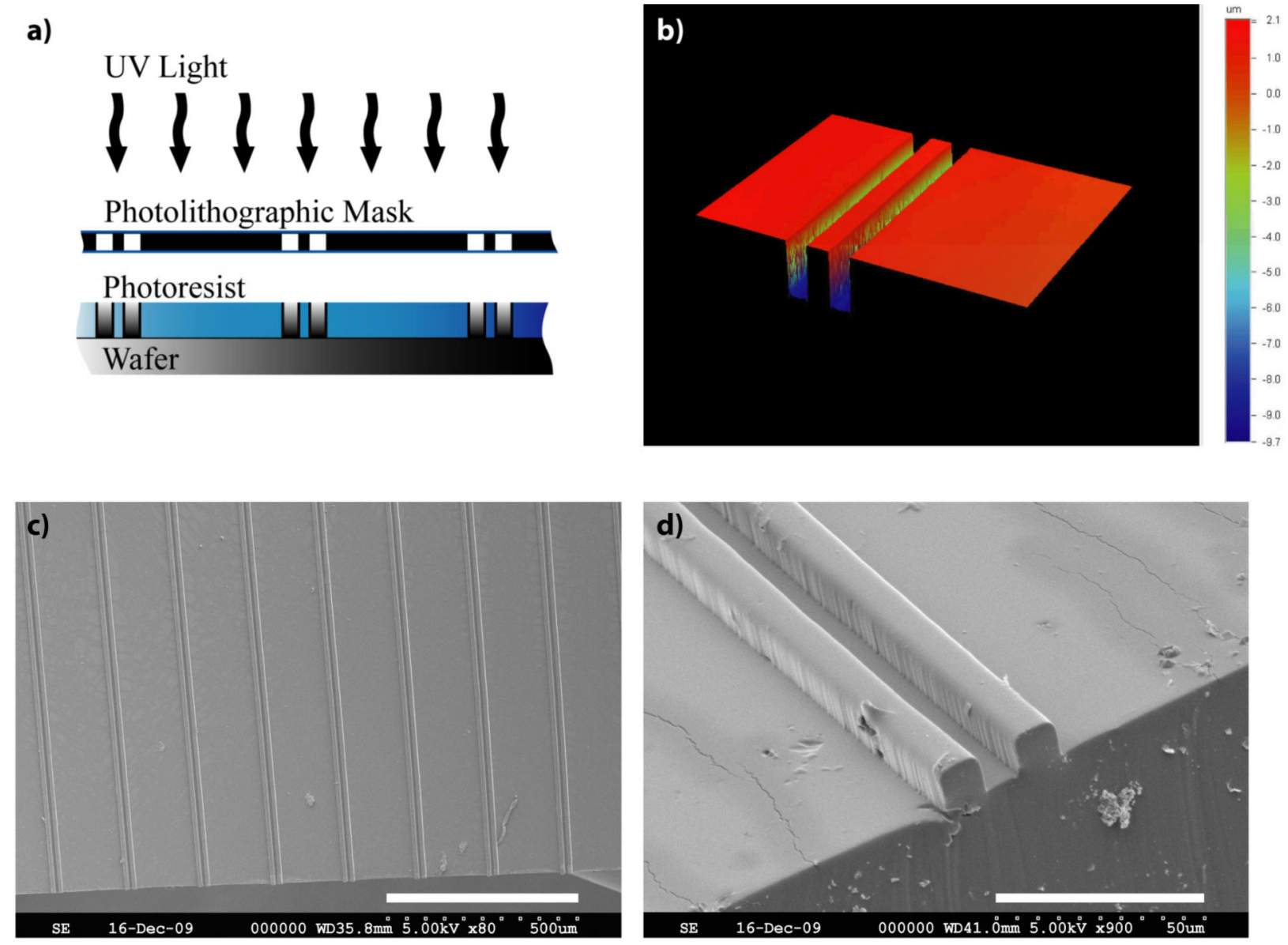

Figure 1. Micropatterning of poly(glycerol sebacate)(PGS)

(a) schematic depicting UV light projection through a mask onto a silicon wafer, (b) interferometry of resulting master showing double grooves, (c,d) SEMs at low-and highmagnification of membranes with micropatterning. Scale bars: (c) $500 \mu \mathrm{m}$, (d) $50 \mu \mathrm{m}$. 
a)
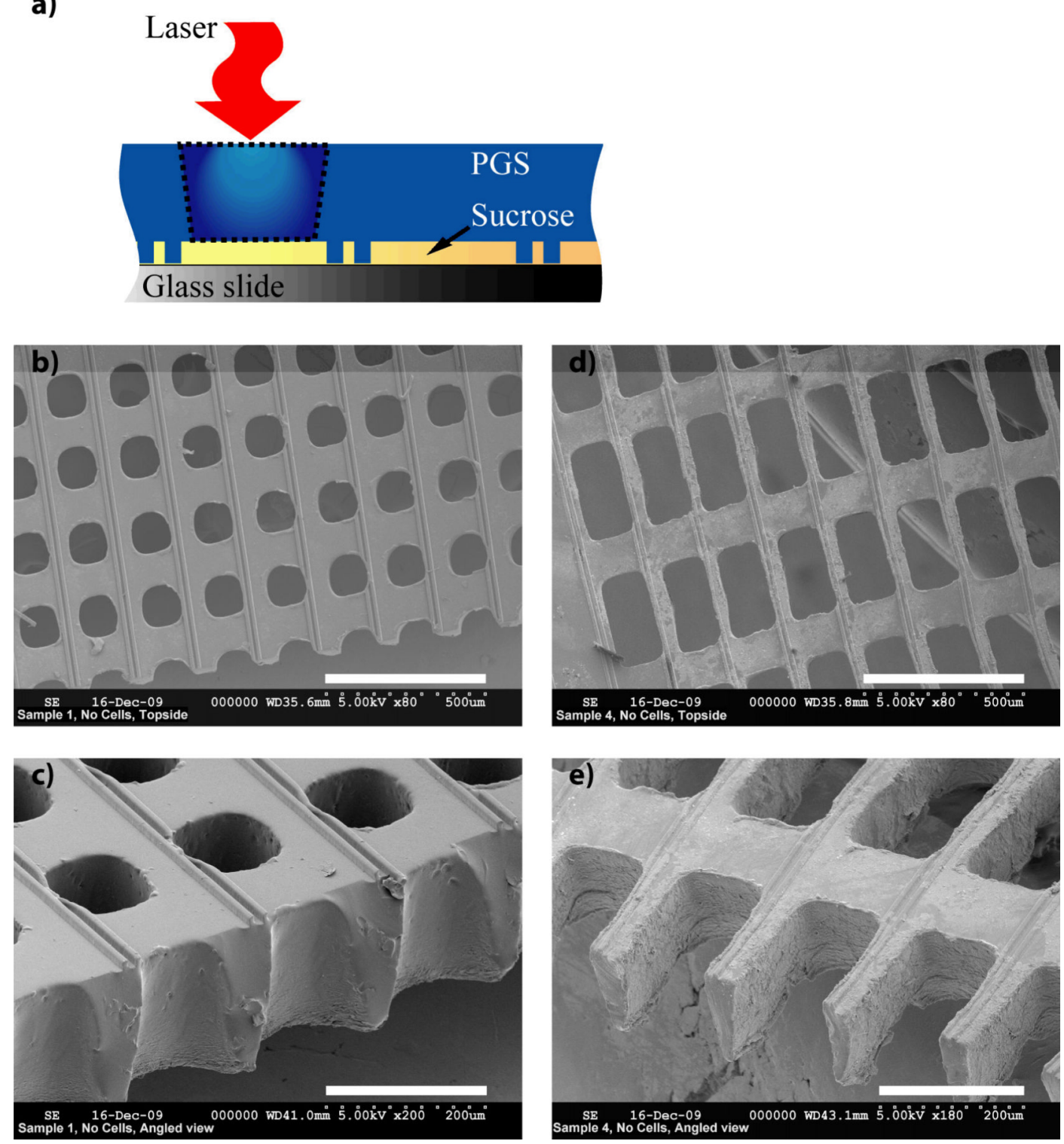

Figure 2. Laser microablation of PGS

(a) schematic of method (laser directed through back side of patterned membrane), (b,c,d,e) SEMs at low- and high magnification of membranes with micropatterning and (b,c) square pores or (d,e) anisotropic rectangular pores. Scale bars: (b-d) $500 \mu \mathrm{m}$, (c-e) $200 \mu \mathrm{m}$. 
a)

\section{Elastic Modululs at $10 \%$ strain}

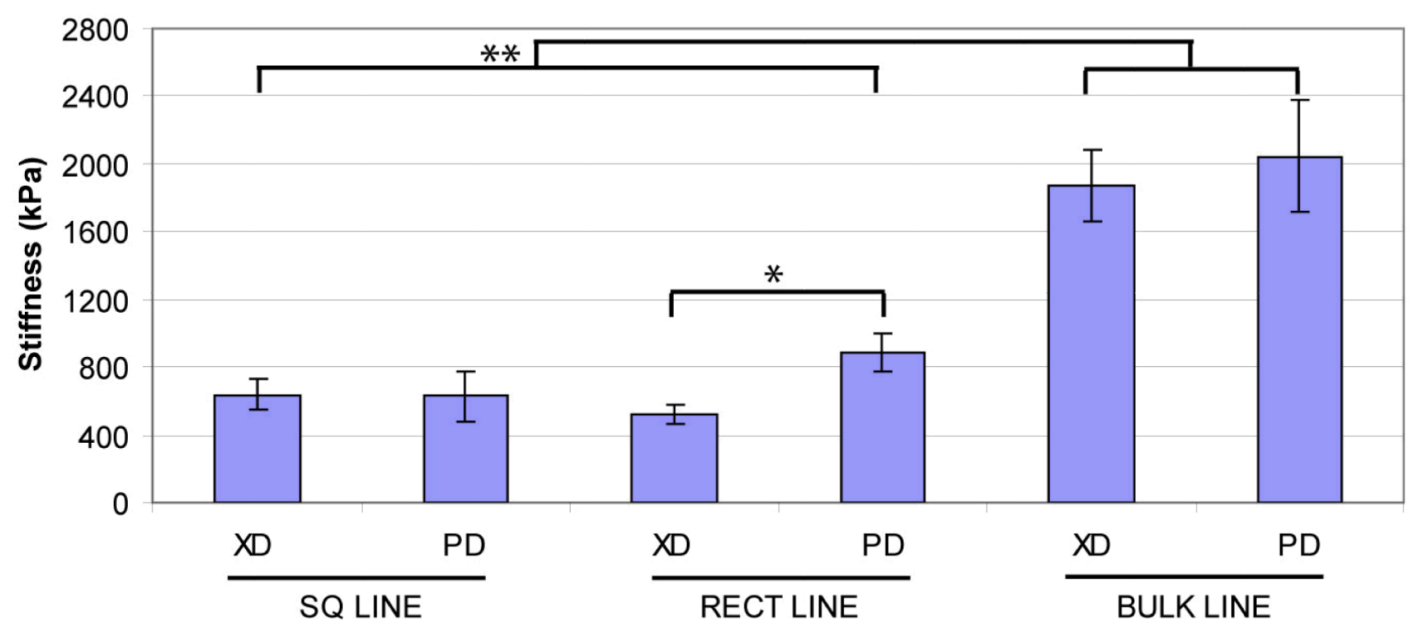

b) Ultimate Tensile Strength

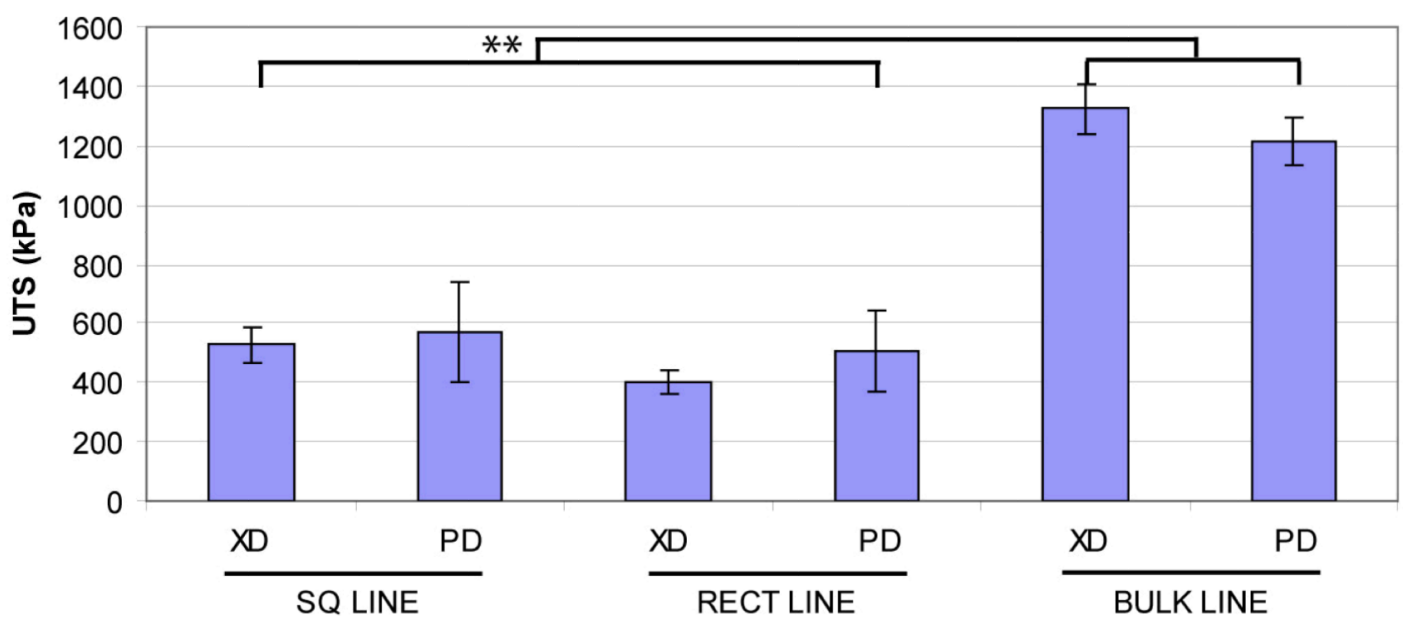

Figure 3. Mechanical properties of PGS membranes and porous scaffolds, as determined by uniaxial tensile testing

(a) Elastic modulus (E) and (b) Ultimate tensile strength (UTS) measured for three types of specimens with gratings: PGS membranes (BULK LINE) and PGS scaffolds from the SQ LINE and RECT LINE groups. Tensile stretch was applied in two directions: parallel or orthogonal to the gratings (preferred direction, $\mathrm{PD}$, and cross-preferred direction, XD). Data represent average \pm standard deviation. $*=p<0.05, * *=p<0.01$. 

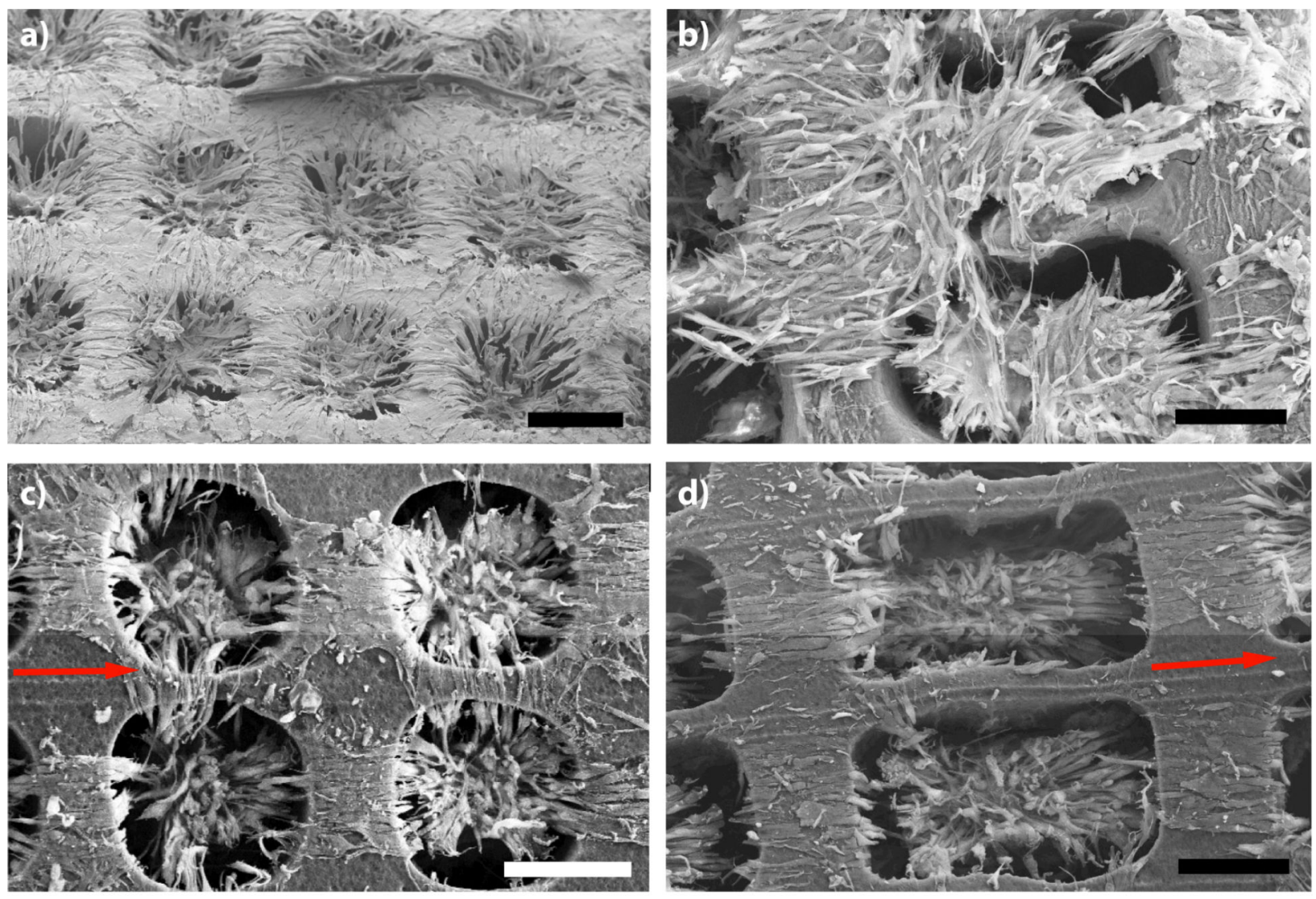

Figure 4. Scanning electron micrographs of C2C12 muscle cells cultured on PGS scaffolds (a, b) Square and rectangular pores without micropatterning, respectively; (c, d) square and rectangular pores with gratings, respectively. Scale bars: (a-d) $100 \mu \mathrm{m}$. Arrows (c,d) indicate grating direction. 

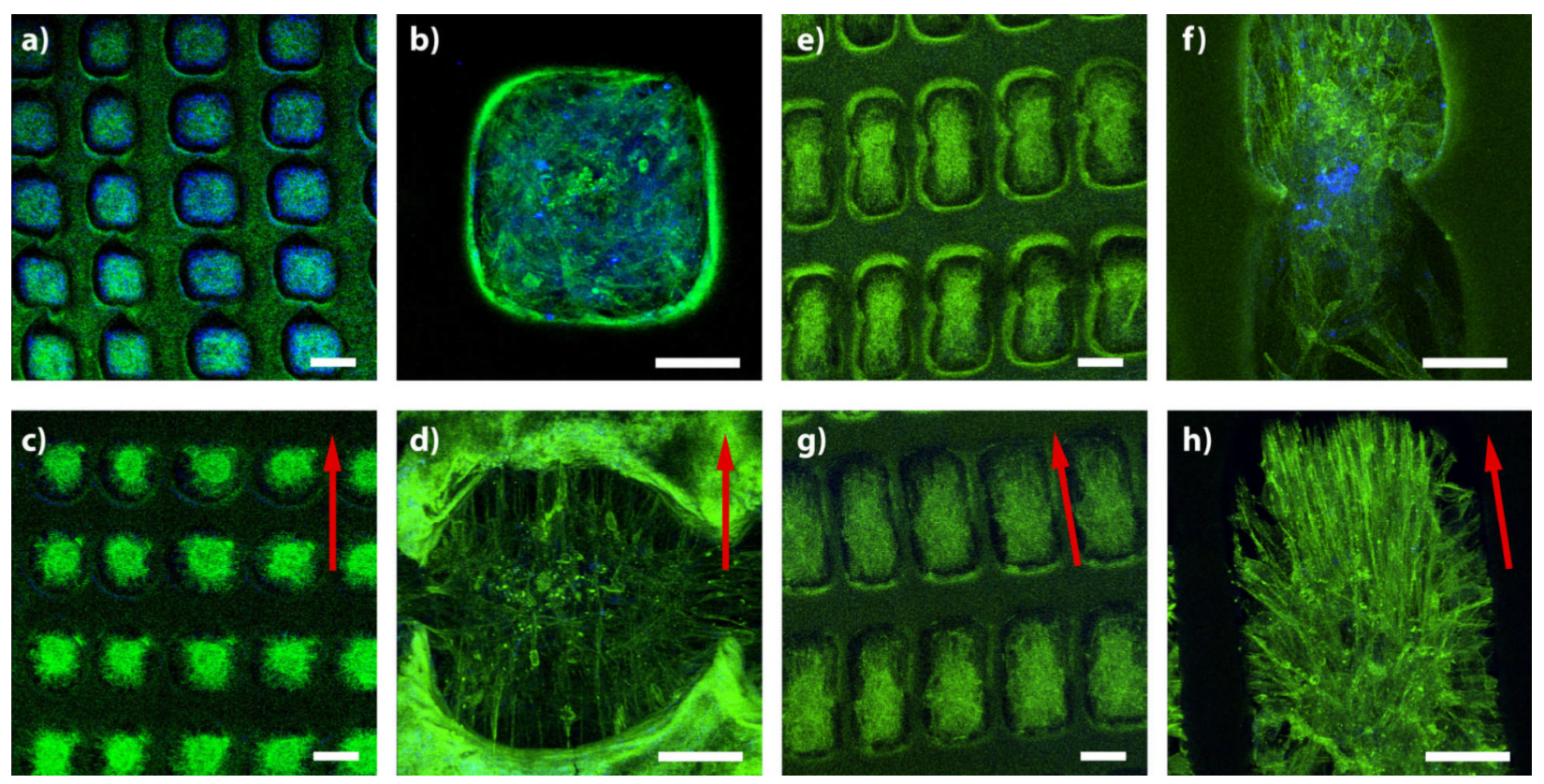

Figure 5. Confocal laser micrographs of C2C12 muscle cells cultured on PGS scaffolds after actin-phalloidin actin staining

(a,b) Square pores without micropatterning; (c,d) square pores with gratings; (e,f) rectangular pores without micropatterning; $(\mathbf{g}, \mathbf{h})$ rectangular pores with gratings. Scale bars: (a,c,e,g) $100 \mu \mathrm{m}$; (b,d,f,h) $50 \mu \mathrm{m}$. Arrows (c,d,g,h) indicate grating direction. 
a)

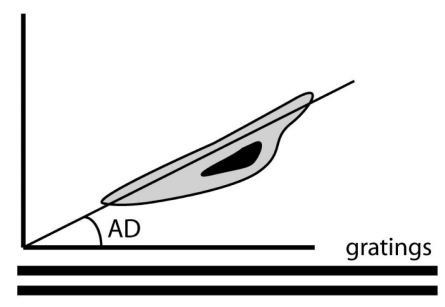

c)

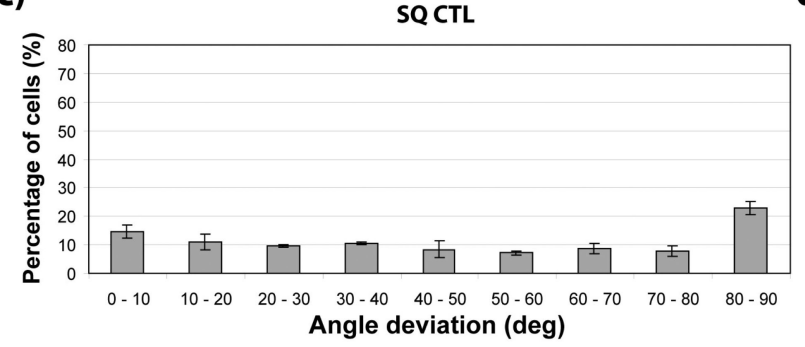

e)

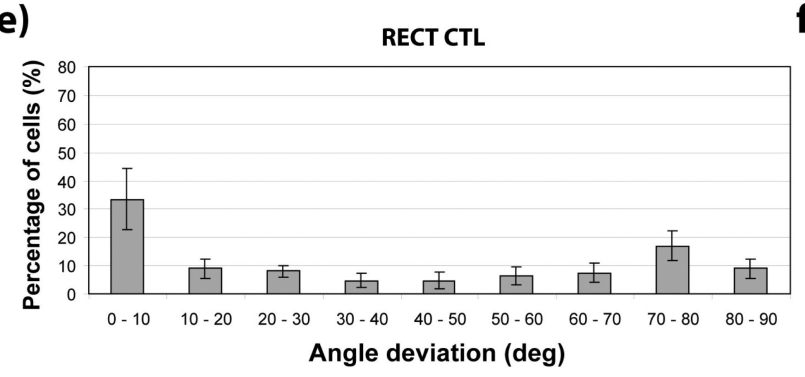

b)

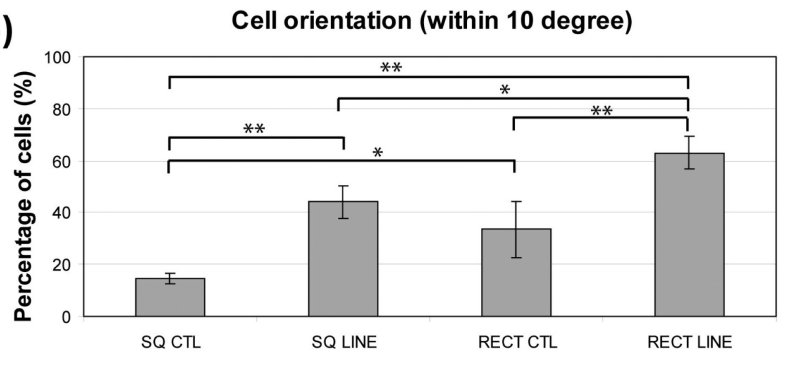

d)

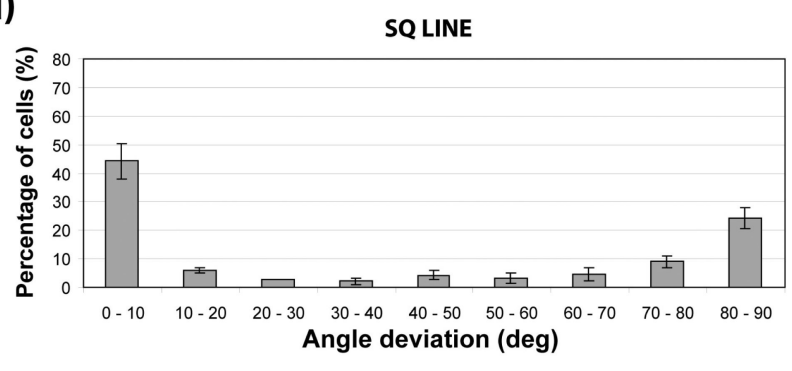

f)

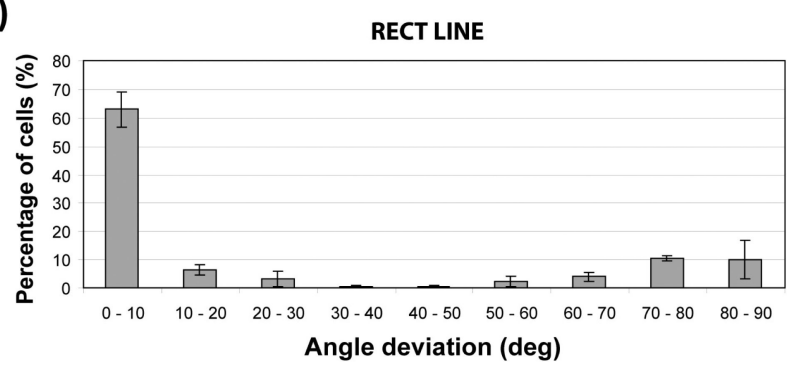

Figure 6. Orientation of $\mathrm{C2C12}$ muscle cells cultured on PGS scaffolds

(a) Schematic of cell long axis angle deviation relative to grating direction. Cell alignment (within a 10 degree angle deviation threshold) based SEM images (b) for all four groups of scaffolds, (c) square pores without micropatterning, (d) square pores with gratings, (e) rectangular pores without micropatterning; (f) rectangular pores with gratings. Data represent average \pm standard deviation. $*=\mathrm{p}<0.05, * *=\mathrm{p}<0.01$. 